\title{
STRATEGI PROMOSI PENGELOLAAN WISATA PANTAI UNTUK MENINGKATKAN KUNJUNGAN WISATAWAN PASCA TSUNAMI SELAT SUNDA DI KABUPATEN PANDEGLANG
}

\author{
Ihwan Satria Lesmana'), Abdul Bahits' ${ }^{2)}$, Mohamad Bayi Tabrani ${ }^{3)}$ \\ Email: ${ }^{1)}$ Ihwasatrialesmana.binabangsa@gmail.com, ${ }^{2)}$ ab.binabangsa@gmail.com, \\ ${ }^{3)}$ muhammadbayitabrani.binabangsa@gmail.com \\ 1,2,3) Fakultas Ekonomi \& Bisnis Universitas Bina Bangsa
}

\begin{abstract}
Abstrak
Sektor pariwisata pantai Kabupaten Pandeglang Banten, merupakan sektor yang diunggulkan dan berkontribusi terhadap Pendapatan Daerah Kabupaten Pandeglang. Tsunami selat sunda yang terjadi pada tanggal 22 Desember 2018, telah menghancurkan wisata Pantai yang ada di Kabupaten Pandeglang mulai dari Kawasan Pantai Carita sampai Kecamatan Sumur. Tujuan penelitian ini dilakukan untuk mengetahui dan menganalisa penerapan strategi promosi pengelolaan wisata pantai pasca tsunami Selat Sunda yang dilakukan oleh Dinas Pariwisata Kabupaten Pandeglang bekerja sama dengan beberapa pelaku usaha wisata yang ada di sekitar pantai di Kabupaten Pandeglang. Metode analisis yang digunakan dalam penelitian ini yaitu metode analisis SWOT dengan menganalisa kekuatan, kelemahan, peluang dan ancaman yang dimilki potensi wisata pantai yang ada di Kabupaten Pandeglang. Hasil dari penelitian ini menunjukan perlu adanya penerapan beberapan strategi diantaranya: strategi promosi yang berkelanjutan, startegi pengembangan sumber daya manusia, strategi pengembangan potensi wisata pantai, strategi engembangan kelembagaan, diharapakan dengan penerapan beberapa strategi tersebut diatas dapat membantu dalam meningkatkan kunjungan wisatawan ke wisata pantai yang ada di Kabupaten Pandeglang Pasca Tsunami Selat Sunda.
\end{abstract}

Kata kunci: Strategi, Promosi, Wisata, Pantai, Tsunami.

\begin{abstract}
The coastal tourism sector of Pandeglang Regency, Banten, is a sector that is favored and contributes to the Regional Revenue of Pandeglang Regency. The Sunda Strait tsunami that occurred on 22 December 2018, has destroyed beach tourism in Pandeglang Regency starting from the Carita Beach Area to Sumur District. The purpose of this study was to determine and analyze the implementation of the promotion strategy for coastal tourism management after the Sunda Strait tsunami carried out by the Pandeglang Regency Tourism Office in collaboration with several tourism businesses around the coast in Pandeglang Regency. The analytical method used in this research is the SWOT analysis method by analyzing the strengths, weaknesses, opportunities, and threats that have the potential for coastal tourism in Pandeglang Regency. The results of this study indicate the need to implement several strategies including sustainable promotion strategies, human resources development strategies, coastal tourism potential development strategies, institutional development strategies, it is hoped that the implementation of some of the strategies mentioned above can help increase tourist visits to coastal tourism. in Pandeglang Regency Post-Sunda Strait Tsunami.
\end{abstract}

Keywords: Strategy, Promotion, Tourism, Beach, Tsunami.

\section{PENDAHULUAN}

Negara Indonesia adalah salah satu negara kepulauan yang banyak memiliki keindahan alam wisata pantai dan tempat-tempat wisata lainya seperti seni budaya, keindahan alam, adat istiadat, dan lain-lain, yang dapat mendukung perkembangan dan pertumbuhan pariwisata. 
Keberadaan letak geografis Indonesia yang memiliki banyak pesona keindahan dan sumber daya alam memberikan peluang bagi pemerintah untuk menjadikan sektor pariwisata sebagai sektor unggulan yang dapat berpengaruh dalam peningkatan pendapatan nasional.Keanekaragaman seni budaya juga menjadi salah satu daya tarik wisata kultural yang mampu mendorong keinginan wisatawan mancanegara untuk berwisata ke Indonesia.Dengan banyaknya potensi pariwisata yang di milki Indonesia diharapkan dapat membantu pendapatan negara dalam memajukan perekonomian secara nasional.

Menurut Peraturan Pemerintah terkait Kepariwisataan yaitu Undang-Undang Republik Indonesia Nomor 10 Tahun 2009 tentang Kepariwisataan disahkan Presiden Dr. H. Susilo Bambang Yudhoyono pada tangal 16 Januari 2009 di Jakarta. UU Nomor 10 Tahun 2009 tentang Kepariwisataan diundangkan pada tanggal 16 Januari 2009 oleh Menkumham Andi Mattalatta dan ditempatkan pada Lembaran Negara Republik Indonesia Tahun 2009 Nomor 11. Penjelasan Atas Undang-Undang Republik Indonesia Nomor 10 Tahun 2009 tentang Kepariwisataan ditempatkan dalam Tambahan Lembaran Negara Republik Indonesia Nomor 4966, agar semua orang mengetahuinya. Pariwisata ialah aktivitas perjalanan yang dilakukan sementara waktu dari tempat tinggal semula ke daerah tujuan dengan alasan bukan untuk menetap atau mencari nafkah melainkan hanya untuk memenuhi rasa ingin tahu, menghabiskan waktu senggang atau libur dan tujuan-tujuan lainnya (Khotimah \& Wilopo, 2017).

Selain itu Pariwisata merupakan suatu perjalanan yang terencana, yang dilakukan secara individu maupun kelompok dari satu tempat ke tempat lain dengan tujuan untuk mendapatkan suatu bentuk kepuasan dan kesenangan semata (Suwantoro, 2002). Keberadaan sektor pariwisata saat ini telah menjadi aspek penting dalam kemajuan perekonomian suatu negara. Dunia Pariwisata menjadi pilihan utama dalam pengembangan wilayah suatu negara. Perkembangan sektor pariwisata telah mengalami banyak perubahan baik perubahan bentuk, pola dan sifat kegiatan perjalanan destinasi wisata, dan lain-lain. Proses pembangunan wisata di suatu daerah dapat membuka daya tarik wisata baru bagi para wisatawan, baik wisatawan asing maupun lokal. Keberadaan potensi pariwisata yang ada di wilayah Indonesia sangat banyak dapat mengangkat perekonomian dan pendapatan negara, setiap potensi wisata yang ada dikelola dengan baik, baik oleh pemerintah maupun pihak-pihak swasta yang bergerak dalam dunia usaha wisata tersebut, sehingga banyaknya kunjungan wisatawan yang berkunjung akan berpengaruh terhadap naiknya devisa atau pendapatan negara tersebut. Perlunya kegiatan promosi juga sangat perlu dimana promosi adalah aktivitas, serangkaian intuisi, dan proses menciptakan, mengkomunikasikan, menyampaikan, dan mempertukarkan tawaran (offerings) yang bernilai bagi pelanggan, klien, mitra, dan masyarakat umum menurut Tjiptono dalam (Fachriza \& Moeliono, 2017). Pandeglang merupakan salah satu Kabupaten di Provinsi Banten yang menjadi kawasan pengembangan pariwisata karena memiliki banyak potensi pariwisata pantai yang banyak dan menarik, karena berada terletak di kawasan ujung pulau jawa dan selat sunda. Sektor pariwisata pantai di Kabupaten Pandeglang merupakan sektor yang diunggulkan dan banyak memberikan kontribusi terhadap Pendapatan Daerah Kabupaten Pandeglang itu sendiri dalam setiap periodenya. Hal ini dikarenakan oleh banyaknya potensi daya tarik wisata pantai dan pesonan keindahan kawasan wisata pantai yang ada di Kabupaten Pandeglang. Kegiatan pengembangan terhadap potensi wisata pantai yang ada di Kabupaten Pandeglang perlu dikembangkan dengan baik karena Kabupaten Pandeglang memiliki tingkat ketergantungan yang besar dari sektor pariwisata pantai yang dimilikinya.

\section{Tabel 1.}

Daftar Nama Wisata Pantai yang ada di Kabupaten Pandeglang

\begin{tabular}{|c|l|l|}
\hline NO. & Nama Wisata Pantai & \multicolumn{1}{c|}{ Alamat } \\
\hline 1. & Pantai Carita & Carita Pandeglang \\
\hline 2. & Pantai Batu Cihideung & Carita Pandeglang \\
\hline 3. & Pantai Kharisma & Carita Pandeglang \\
\hline 4. & Pantai Tanjung Lesung & $\begin{array}{l}\text { Panimbang } \\
\text { Pandeglang }\end{array}$ \\
\hline 5. & Pantai Sumur & Sumur Pandeglang \\
\hline 6. & Pantai Labuan & Labuan Pandeglang \\
\hline 7. & Pulau Umang & Sumur Pandeglang \\
\hline 8. & Pulau Oar & Sumur Pandeglang \\
\hline 9 & Pantai Ujung Kulon & $\begin{array}{l}\text { Ujung } \\
\text { Pandeglang }\end{array}$ \\
\hline 10 & Pantai Anyer & Anyer Serang \\
\hline
\end{tabular}

Sumber: Data Dinas Pariwisata Kabupaten Pandeglang

Bencana alam Tsunami Selat Sunda yang terjadi pada tanggal 22 Desember 2018, telah menghancurkan wisata Pantai yang ada di Kabupaten Pandeglang mulai dari Kawasan Pantai Carita sampai Kecamatan Sumur. Badan Nasional Penanggulangan Bencana (BNPB) mencatat, jumlah korban meninggal dunia akibat tsunami Selat Sunda meningkat menjadi 437 orang. Dari jumlah total korban, sebanyak 426 jenazah sudah diidentifikasi dan dimakamkan. Sementara sembilan jenazah hingga saat ini belum teridentifikasi. Jumlah itu meliputi korban di lima kabupaten, yaitu Kabupaten Serang, Pandeglang, Lampung Selatan, Pesawaran dan Tanggamus. Dari lima kabupaten, daerah paling parah terdampak tsunami adalah Kabupaten Pandeglang. Tercatat, korban meninggal dunia di wilayah ini paling banyak, yaitu 296 orang."Paling parah, baik jumlah kerugian maupun 
korban adalah Kabupaten Pandeglang. Korban kebanyakan adalah wisatawan yang sedang berkunjung ke tempat wisata, ditambah masyarakat lokal. Badan Nasional Penanggulangan Bencana (BNPB) Provinsi Banten mencatat, wilayah yang terdampak tsunami di Kabupaten Pandeglang mencakup 13 kecamatan, dimulai dari kawasan Pantai Carita, hingga Kecamatan Sumur. Selain korban meninggal, tercatat 14.059 orang lukaluka, 16 orang hilang, dan 33.721 mengungsi. BNPB juga mencatat, akibat tsunami yang terjadi, sebanyak 2.752 rumah rusak, 92 penginapan dan warung rusak, 510 perahu dan kapal rusak, serta 147 kendaraan rusak.

Tabel 2.

Daftar Kunjungan Wisatawan Pasca Tsunami Selat Sunda

\begin{tabular}{|l|c|c|}
\hline No & $\begin{array}{c}\text { Tahun } \\
\text { Kunjungan } \\
\text { Wisata }\end{array}$ & $\begin{array}{c}\text { Jumlah } \\
\text { KunjunganWisata }\end{array}$ \\
\hline 1. & 2016 & 3.802 .733 \\
\hline 2. & 2017 & 3.833 .001 \\
\hline 3. & 2018 & 3.105 .051 \\
\hline 4. & 2019 & 1.406 .393 \\
\hline
\end{tabular}

Sumber: Data Dinas Pariwisata Kabupaten Pandeglang.

Dengan melihat kondisi tersebut diatas, maka kondisi Pariwisata yang ada di Kabupaten Pandeglang, khusus wisata pantai mengalami kehancuran yang luar biasa dan berpengaruh terhadap penurunan kunjungan wisata. Wisatawan, baik yang berasal dari dalam negeri maupun luar negeri akan berpikir panjang untuk berwisata atau berkunjung ke wisata pantai yang ada di Kabupaten Pandeglang karena mereka kekhawatiran dan takut akan adanya tsunami susulan. Disnilah tantangan bagi pihakpihak yang berkepentingan dalam dunia pariwisata yang ada di Kabupaten Pandeglang, diantaranya Dinas Pariwisata Kabupaten Pandeglang pengelola wisata pantai, masyarakat wisata pantai dan lain sebagainya untuk kembali bangkit memajukan pariwisata terutama wisata pantai yang ada di Kabupaten Pandeglang.

Selama ini kegiatan promosi yang dilakukan Dinas Pariwisata Kabupaten Pandeglang dan para pelaku usaha yang ada di kawasan pantai yang ada di Kabupaten belum menunjukan hasil maksimal karena terbentuk anggaran dana dan sumber daya manusia sehingga berpengaruh terhadap kunjungan wisatawan ke kawasan pantai yang ada di kabupaten Pandeglang pasca tsunami selat sunda. Selain itu diperlukan pengelolaan yang baik agar dapat menarik minat wisatawan untuk berkunjung. Artinya bahwa wisatawan memberikan respon positif, Respon merupakan balasan atau tanggapan seseorang terhadap sesuatu. Proses merespon dilatarbelakangi oleh tiga hal yakni sikap, persepsi dan partisipasi (Saputra \& Gede, 2016).

Berdasarkan latar belakang diatas maka dapat dirumuskan masalah yang terjadi adalah:

1. Untuk menerapkan strategi promosi yang tepat dalam meningkatkan kunjungan wisatawan pasca Tsunami Selat Sunda di Kabupaten Pandeglang.

2. Potensi wisata dan produk unggulan apasaja yang dimiliki tempat wisata pantai dalam meningkatkan kunjungan wisatawan pasca Tsunami Selat Sunda di Kabupaten Pandeglang?

\section{METODE PENELITIAN}

Metode yang di gunakan dalam proses penelitian ini adalah metode kualitatif melalui proses observasi, wawancara dan dokumentasi kemudian di sajikan dalam bentuk data dan narasi. Metode analisis yang digunakan dalam penelitian ini yaitu metode analisis SWOT dengan menganalisa kekuatan, kelemahan, peluang dan ancaman yang dimilki potensi wisata pantai yang ada di Kabupaten Pandeglang. Analisis SWOT yang terdiri dari pengambungan unsur kekuatan (Strengths), kelemahan (Weaknesses), peluang (Opportunities), dan ancaman (Threats) yang mampu menghasilkan suatu strategi yang didasarkan pada situasi lingkungan internal dan eksternal (Qamaruddin, Sapar, Risal, \& Hamid, 2019). Adapun informan yang kami wawancarai dalam proses mencari data terkait kegiatan penelitan yang berkaitan dengan promosi wisata pantai pasca tsunmai selat sunda yaitu:

1. Dinas Pariwsiata Kabupaten Pandeglang

2. Pengelola tempat wisata Pantai

3. Pengunjung wisata atau wisatawan

4. Masyarakat sekitar tempat wisata Pantai seperti: pedagang, pengelola wisata, pengelola penginapan, dan lain seabagainya.

\section{HASIL DAN PEMBAHASAN}

Hasil analisis SWOT, Pariwisata Pantai di Kabupaten Pandeglang Banten terutama wisata Pantai dari mulai Pantai Carita sampai Pantai Sumur punya Kekuatan yang luar biasa,karena tidak di miliki daerah lain, juga Peluang yang dimiliki sangat berpotensi untuk bisa di benahi supaya lebih maju ke arah jangka panjang Pasca Tsunami Selat Sunda. Sedangkan Pesaing dan Kelemahan tidak begitu signifikan karena masih di bisa di atasi dengan baik.

\section{Kekuatan}

1. Spesifikasi wisata yang bersifat langka tidak di miliki daerah lain

2. Pantai Ujung Kulon yang memiliki memiliki khas Badak bercula satu

3. Pantai Carita, Pantai Tanjung lesung, Pantai Sumur Pulau Oar Pulau Umang,

4. Pantai menarik dengan ombak dan pasir putihnya. 
5. Wisata pantai yang menimbulkan rasa senang, nyaman, indah dan bersih.

6. Akses mudah di jangkau karena sarana dan prasarana mendukung

\section{Peluang}

1. Mempunyai potensi dalam dan luar negeri

2. Fasilitas wisata yang memadai terutama wisata pantai.

3. Memberikan motivasi bagi daerah untuk menggali potensi wisata daerah.

4. Adanya dukungan pemerintah daerah dan pusat dalam bentuk anggaran

5. Pengelolaan dan pelayanan yang baik

\section{Kelemahan}

1. Kegiatan promosi wisata yang masih kurang

2. Kurangnya acara even yang berhubungan langsung dengan wisata pantai

3. Kurang Sumber Daya Manusia

4. Jam pelayanan yang masih kurang

5. Jarak tempuh yang lumayan jauh

Ancaman

1. Banyak wisata pantai yang ada di daerah lain.

2. Sistem pengawasan pengunjung yang masih manual

3. Kurang kerjasama kemitraan dengan pihak terkait

4. Kurang dukungan dari pemerintah daerah dalam penempatan sumber daya manusia.

5. Masih belum merata pengelolaan daerah wisata pantaiyang ada di Kabupaten Pandeglang.

6. Adanya erusi anak gunung krakatau,berpotensi adanya gempa susulan.

Adapun Beberapa kegiatan promosi yang dilakukan Dinas Pariwisata bekerjasama dengan pihak terkait diantaranya pengelola wisata pantai, dan masyarakat sekitar pantai mulai dari pantai carita sampai pantai tanjung, pantai labuan, pantai sumur, sampai pantai ujung kulon dengan tujuan untuk meningkatkan kunjungan wisatawan pasca Tsunami Selat Sunda diantaranya:

1. Pengembangan Geopark di wilayah pantai yang ada di Kabupaten Pandeglang mulai dari Pantai Carita sampai Pantai Ujung Kulon.

2. Festival Tanjung Lesung

3. Festival Kuliner di Pantai Carita

4. Festival Kuliner di kawasan Reas Area Panimbang

5. Pelatihan Pemandu Wisata Pantai

6. Pelatihan Pelaku Jasa Wisata Pantai

7. Festival lomba Kolecer di Pantai Tanjung Lesung

8. Pembuatan spanduk dengan slogan "Wisata Pantai Pandeglang Aman untuk di Kunjungi “

9. Trauma Hiling Korban Bencana Tsunami Selat Sunda

10. Sosialisasi Sadar Wisata Bagi warga Pandeglang yang ada di sekitar Pantai.
Tabel 3.

Rencana Strategi Promosi wisata Pantai

\begin{tabular}{|c|c|c|}
\hline No & Kriteria & Strategi Promosi \\
\hline 1. & $\begin{array}{l}\text { Strategi } \\
\text { Promosi } \\
\text { Berkelanjutan }\end{array}$ & $\begin{array}{l}\text { 1. Even Promosi Wisata } \\
\text { Pantai yang berkelanjutan. } \\
\text { 2. Media Promosi melalui } \\
\text { Internet atau Media Sosial } \\
\text { lebih efektif dan efisien. } \\
\text { 3. Even Kepariwisataan lebih } \\
\text { di tingkatkan lagi. } \\
\text { 4. Wisatawan menjadi agen } \\
\text { promosi by mouth } \\
\text { promotion. } \\
\text { 5. Tour agent dan Freelance } \\
\text { Blogger aktif dalam } \\
\text { mempromosikan kunjungan } \\
\text { wisata pantai ke Kabupaten } \\
\text { Pandeglang. }\end{array}$ \\
\hline 2. & $\begin{array}{l}\text { Strategi } \\
\text { Sumber Daya } \\
\text { Manusia }\end{array}$ & $\begin{array}{l}\text { 1. Pelatihan Pengelola Wisata } \\
\text { Pantai. } \\
\text { 2. Pelatihan Pemandu Wisata } \\
\text { Pantai } \\
\text { 3. Pelatihan Pelaku Jasa } \\
\text { Wisata Pantai } \\
\text { 4. Pelatihan Pelaku Usaha di } \\
\text { sekitar Pantai } \\
\text { 5. Pelatihan Sadar Wisata } \\
\text { Kepada Warga sekitar } \\
\text { Pantai. }\end{array}$ \\
\hline 3. & $\begin{array}{l}\text { Strategi } \\
\text { Kelembagaan }\end{array}$ & $\begin{array}{l}\text { 1. Adanya Komunitas } \\
\text { Pelaku Usaha Pantai } \\
\text { Korban Tsunami Selat } \\
\text { Sunda. } \\
\text { 2. Bekerja sama Dinas } \\
\text { Pariwisata dan Ekonomi } \\
\text { Kreaatif Kabupaten } \\
\text { Pandeglang lebih aktif } \\
\text { lagi dalam } \\
\text { mempromosikan wisata } \\
\text { pantai Pasca Tsunami } \\
\text { Selat Sunda. } \\
\text { 3. Bekerja sama dengan } \\
\text { Kementrian Pariwisata } \\
\text { Republik Indonesia } \\
\text { 4. Bekerja sama dengan } \\
\text { Dinas Pariwisata Provinsi } \\
\text { Banten. } \\
\text { 5. Bekerja sama dengan } \\
\text { pengelola } \\
\text { Pariwisata. Travel } \\
\text { 6. Bekerja sama dengan } \\
\text { Pengelola wisata pantai. }\end{array}$ \\
\hline
\end{tabular}




\begin{tabular}{|l|l|l|}
\hline & & $\begin{array}{l}\text { 7. } \\
\text { Bekerja sama dengan } \\
\text { BMKG. }\end{array}$ \\
\hline 4. & $\begin{array}{l}\text { Strategi } \\
\text { Potensi Wisata } \\
\text { Pantai }\end{array}$ & $\begin{array}{l}\text { 1. } \\
\text { Pengembangan } \\
\text { Perbaikan Potensi Wisata } \\
\text { Pantai Pasca Tsunami } \\
\end{array}$ \\
& $\begin{array}{l}\text { Selat Sunda. } \\
\text { 2. Pengembangan Geopark } \\
\text { wisata Pantai. } \\
\text { 3. Sampaikan kepada } \\
\text { wisatawan bahwa wisata } \\
\text { Pantai di Kabupaten } \\
\text { Pandeglang aman untuk } \\
\text { di kunjungi. }\end{array}$ \\
\hline
\end{tabular}

Sumber: Dinas Pariwisata Pandeglang

Dengan penerapan beberapa strategi pengembangan promosi diatas, diharapkan ada perubahan ke arah yang lebih baik, sehingga bisa meningkatkan kunjungan wisatawan pasca tsunami selat di Kabupaten Pandeglang.

\section{SIMPULAN DAN SARAN}

\section{Simpulan}

Berdasarkan hasil penelitian dan temuan di lapangan dalam penerapan strategi promosi pengelolaan wisata pantai pasca tsunami selat sunda di kawasan wisata pantai di Kabupaten Pandeglang belum optimal sehingga perlu adanya penerapan beberpa startegi yaitu: strategi promosi yang berkelanjutan,strategi pengembangan sumber daya manusia, strategi pengembangan dna perbaikan potensi wisata pantai dan strtaegi pengembangan kelembagaan.Pariwisata Pantai di Kabupaten Pandeglang Banten terutama wisata pantai dari mulai pantai carita sampai pantai sumur punya kekuatan yang luar biasa, karena tidak di miliki daerah lain, juga peluang yang dimiliki sangat berpotensi untuk bisa di benahi supaya lebih maju ke arah jangka panjang pasca tsunami selat sunda. Sedangkan ancaman dan kelemahan tidak begitu signifikan karena masih di bisa di atasi dengan baik.

\section{Saran}

Berdasarkan hasil kesimpulan, peneliti perlu memberikan beberapa saran. Pertama, Jenis kegiatan Promosi yang dilakukan oleh Dinas Pariwisata Kabupaten Pandeglang Banten bekerjasama denga para pelaku usahawisata pantai yang ada di Kabupaten Pandeglang adalah ikut dalam kegiatan festival, pameran wisata, memasang iklan promosi melalui media cetak dan elektronik dan mengadakan promosi pariwisata yang berkelanjutan. Kedua, Jenis kegiatan Promosi Pariwisata melalui teknologi informasi dengan media internet dan media sosial lebih efektif dan efisien karena jaman sekarang semua manusia menggunakan teknologi informasi dalam hal ini media social. Ketiga, Memberikan pelatihan sadar wisata kepada para kelompok sadar wisata yang ada di kawasan wisata pantai. Keempat, Memberikan pelatihan teknologi informasi dalam hal ini media sosial kepada warga sekitar pantai. Terakhir, sampaikan ke masyarakat luas bahwa wisata pantai yang ada di Kabupaten Pandeglang aman untuk di kunjungi.

\section{DAFTAR PUSTAKA}

Fachriza, F. I., \& Moeliono, N. (2017). Pengaruh Bauran Pemasaran Terhadap Keputusan Pembelian Rokok Mild. Jurnal Ecodemica: Jurnal Ekonomi, Manajemen, Dan Bisnis. https://doi.org/10.31311/JECO.V1I2.1332

Khotimah, K., \& Wilopo, W. (2017). Strategi pengembangan destinasi pariwisata budaya (Studi kasus pada kawasan Situs Trowulan sebagai Pariwisata Budaya Unggulan di Kabupaten Mojokerto). Jurnal Administrasi Bisnis, 42(1), 5665.

Peraturan Pemerintah terkait Kepariwisataan yaitu Undang-Undang Republik Indonesia Nomor 10 Tahun 2009 tentang Kepariwisataan.

Qamaruddin, M. Y., Sapar, S., Risal, M., \& Hamid, R. S. (2019). STRATEGI SIAPA MAU KERJA APA DALAM PENGEMBANGAN MODEL QUADRUPLE HELIX SINERGITAS ANTARA PEMERINTAH, PERGURUAN TINGGI, INDUSTRI, DAN MASYARAKAT. Jurnal Manajemen STIE Muhammadiyah Palopo, 4(2). 13-23.

Saputra, G., \& Gede, I. (2016). Respon Wisatawan Terhadap Pengembangan Batur Global Geopark Bali. Jurnal Master Pariwisata (JUMPA), 2(2), 77-94.

Suwantoro, G. (2002). Dasar-Dasar Pariwisata. Yogyakarta: Andi. 